\title{
Free movement and special non-contributory benefits for disabled people: between the devil and the deep blue sea
}

\author{
Simon Roberts ${ }^{1}$ \\ Published online: 5 September 2016 \\ (C) The Author(s) 2016. This article is published with open access at Springerlink.com

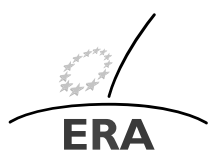 \\ EUROPÄISCHE RECHTSAKADEMIE \\ ACADEMY OF EUROPEAN LAW \\ ACADEMIE DE DROIT EUROPEEN \\ ACCADEMIA DI DIRITTO EUROPEO \\ TRIER - TREVES - TREVIRI
}

\begin{abstract}
Special non-contributory benefits (SNCBs) include benefits intended solely for the specific protection of disabled people. SNCBs are not exportable under EU law. This paper asks whether SNCBs discriminate against disabled people exercising their right to free movement. Two further questions will be explored in this article: Firstly, whether the difference of treatment identified falls within the scope of EU law (including under the obligations deriving from the UN Convention on the Rights of Persons with Disabilities), and secondly, whether any discrimination could be justified. It is proposed that SNCBs are included in a review of the compatibility of EU legislation with the UN Convention.
\end{abstract}

Keywords Disability · Free-movement, special-non-contributory-benefits · UNCRPD

\section{Introduction}

Regulation 1247/92 introduced a new category of 'special non-contributory benefit' to social security coordination in the European Union (EU). Special non-contributory benefits include benefits intended solely for the specific protection of disabled people (Art. 70 (2)(a)(ii)). Special non-contributory benefits are not exportable. This paper asks whether Article 70 of Regulation $883 / 04^{1}$ discriminates against people with dis-

\footnotetext{
${ }^{1}$ Regulation (EC) No 883/2004 of the European Parliament and of the Council of 29 April 2004 on the coordination of social security systems, Official Journal of the European Union, OJ L 200 of 7 June 2004, pp. $1-49$.
}

$凶$ Dr. S. Roberts, Associate Professor of Public and Social Policy simon.roberts@nottingham.ac.uk

1 School of Sociology and Social Policy, University of Nottingham, B39, Law and Social Science Building, University Park, Nottingham NG7 2RD, UK 
abilities in exercising their right to free movement; and whether this is in keeping with the EU's obligations under the United Nations Convention on the Rights of Persons with Disabilities.

\section{Free movement and social security}

The drafters of the Treaty of Rome recognised that the conditions of entitlement contained in the Member States' different social security systems could be a barrier to the right to free movement enshrined in the Treaty. ${ }^{2}$ The Treaty of Rome itself provided for necessary measures to be adopted in the field of social security to support free movement for workers, including:

(1) aggregation, for the purpose of acquiring and retaining the right to benefit and of calculating the amount of benefit, of all periods taken into account under the laws of the several countries

(2) payment of benefits to persons resident in the territories of Member States.

The first measure to be adopted to coordinate social security for migrant workers in the then European Economic Community (EEC) was Regulation 3/58 (along with implementing Regulation No. 4). These have evolved into Regulations 883/04 and 987/09. Regulation 883/04 achieves coordination through four key principles—one of which is export of benefits. The principle of portability operates differently across different benefits. The principle of territoriality continues to operate in whole or in part for shorter term benefits: including sickness and maternity benefits, which may be exported under certain limited conditions; while the export of unemployment benefits applies only in the cases provided for by Articles 64 and 65 of the regulation and within prescribed time limits. Family benefits may be payable where family members live in a different country to the 'worker'. Healthcare is generally provided by the country of residence, with costs reimbursed by the 'competent' country. 3 'Special non-contributory benefits', which are the subject of this paper, are not exportable.

The category of 'special non-contributory benefits' arose from the distinction made by Regulation 3/58 between 'social security' and 'social assistance' with coordination applying to 'social security' only; and what is 'social security' soon became contested. ${ }^{4}$ The question of what is included within and what is excluded from the material scope of coordination has been ruled upon by the Court of Justice of the European Union (CJEU) in a series of judgements from Frilli $(\mathrm{C}-1 / 72)^{5}$ to Newton $(\mathrm{C}-356 / 89)^{6}$ that brought benefits, whether or not they were categorised as social assistance by the Member State, within the coordinating regulations if they were: entitlement based (Frilli C-1/72); and related to one of the contingencies enumerated in

\footnotetext{
${ }^{2}$ Watson [9]; Holloway [3].

${ }^{3}$ Roberts [6].

${ }^{4}$ Roberts [6].

${ }^{5}$ Case 1/72 Frilli [1972] ECR 471.

${ }^{6}$ Case 356/89 Newton [1991] ECR 3017.
} 
Article 4(1) of Regulation 1408/71 (now Article 3(1) of Regulation 883/04) (Hoeckx, C248/83). ${ }^{7}$

However, changes were taking place in member countries' social security systems with most transferring social assistance from discretion to rule-based entitlement. At the same time, many countries introduced non-contributory categorical benefits, including benefits to address specific needs of people with disabilities, which blurred the lines between contributory social insurance and non-contributory social assistance. $^{8}$

As a consequence, Regulation 1247/92 was introduced to create a new category of 'special non-contributory benefit' to coordination, defined as benefits granted to provide substitute, supplementary and ancillary protection against social contingencies covered by the branches now referred to in Article 3(1)(a)-(j) of Regulation 883/04 or intended solely for the specific protection of disabled people (Art. 70 (2)(a)(ii)). The benefits considered to be special non-contributory are agreed between Member States and the European Legislature and are then listed in Annex X of Regulation 883/04. There are around 70 separate benefits currently listed in Annex X. Special non-contributory benefits are not exportable under Regulation 883/04. The CJEU subsequently confirmed this position in two UK cases Snares (C-20/96) ${ }^{9}$ and Partridge (C-297/97). ${ }^{10}$

\section{Non discrimination against people with disabilities-a fundamental principle of the European Union}

There are several sources of law prohibiting discrimination against disabled people in the European Union. Article 10 of the Treaty on the Functioning of the European Union (TFEU) provides that:

"In defining and implementing its policies and activities, the Union shall aim to combat discrimination based on sex, racial or ethnic origin, religion or belief, disability, age or sexual orientation."

While Article 19 TFEU provides the legal basis for the EU to combat disability discrimination:

"Without prejudice to the other provisions of the Treaties and within the limits of the powers conferred by them upon the Union, the Council, acting unanimously in accordance with a special legislative procedure and after obtaining the consent of the European Parliament, may take appropriate action to combat discrimination based on sex, racial or ethnic origin, religion or belief, disability, age or sexual orientation."

Non discrimination against people with disabilities is a fundamental principle of the European Union. Article 21 of the Charter of Fundamental Rights of the European

\footnotetext{
${ }^{7}$ Case 249/83 Hoeckx [1985] ECR 982.

${ }^{8}$ Roberts [6].

${ }^{9}$ Case C-20/96 Snares [1997] ECR I-6057.

${ }^{10}$ Case C-297/96 Partridge v Adjudication Officer [1998] ECR I-3467.
} 
Union ${ }^{11}$ provides that: "Any discrimination based on any ground such as sex, race, colour, ethnic or social origin, genetic features, language, religion or belief, political or any other opinion, membership of a national minority, property, birth, disability, age or sexual orientation shall be prohibited." While Article 26 states that: "The Union recognises and respects the right of persons with disabilities to benefit from measures designed to ensure their independence, social and occupational integration and participation in the life of the community."

Council Directive 2000/78/EC ${ }^{12}$ lays down a general framework for combating discrimination on the grounds of religion or belief, disability, age or sexual orientation as regards employment and occupation, with a view to putting into effect the principle of equal treatment in the Member States (Art. 1).

There are also potential sources of protection against discrimination for people with disabilities in international human rights law. The European Union is a Party to the United Nations Convention on the Rights of Persons with Disabilities (UNCRPD). The Convention-which was adopted by the General Assembly on 13 December 2006 and opened for signature by all States and by regional integration organisations on 30 March 2007-is the first international legally binding instrument that establishes rights and minimum standards for disabled people, and is the first human rights convention to which the EU is a Party. Since the Council adopted the Decision for the conclusion of the Convention on 26 November 2009, all EU Member States have signed; although Finland, Ireland and the Netherlands have signed, they have not yet ratified the Convention. Twenty-three EU countries have also signed its Optional Protocol, and 21 have ratified it. ${ }^{13}$

Thus, the EU and Member States as Parties are committed to upholding and protecting the rights of disabled people as enshrined in the UN Convention. Article 2 of the UN Convention on the Rights of Persons with Disabilities states that:

"Discrimination on the basis of disability" means any distinction, exclusion or restriction on the basis of disability which has the purpose or effect of impairing or nullifying the recognition, enjoyment or exercise, on an equal basis with others, of all human rights and fundamental freedoms in the political, economic, social, cultural, civil or any other field. It includes all forms of discrimination, including denial of reasonable accommodation" (Art. 2).

The EU Framework for the UN Convention on the Rights of Persons with Disabilities states that: "As a party to the UN Convention on the rights of persons with disabilities, the EU has a Framework that promotes, protects and monitors the implementation of the Convention in matters of EU competence: EU legislation and policy..." 14

\footnotetext{
${ }^{11}$ Charter of Fundamental Rights of the European Union, OJ C 364 of 8 December 2000, pp. 1-22.

${ }^{12}$ Council Directive 2000/78/EC of 27 November 2000 establishing a general framework for equal treatment in employment and occupation, OJ L 303 of 2 December 2000, pp. 16-22.

${ }^{13}$ European Commission, Employment, Social Affairs and Inclusion, http://ec.europa.eu/social/main.jsp? catId $=1138$.

${ }^{14}$ EU Framework for the UN Convention on the Rights of Persons with Disabilities http://ec.europa.eu/ social/main.jsp?catId=1189\&langId=en.
} 
The key elements of the UN Convention on the Rights of Persons with Disabilities are reflected in the European Disability Strategy 2010-2020. ${ }^{15}$ Eight areas for joint action between the EU and EU countries are highlighted in this strategy. These include:

- Participation: ensuring that people with disabilities can exercise all their fundamental rights as European citizens

- Equality: ensuring that policies are implemented (both at EU and national level) that promote equality.

\section{Establishing discrimination on the ground of disability}

The question at issue is whether the denial of exportability of special non-contributory benefits on the ground that they are "solely specific protection for the disabled, closely linked to the said person's social environment in the Member State concerned" discriminates against people with a disability?

There are two forms of discrimination: Direct discrimination and Indirect discrimination. Article 2 of Council Directive 2000/78/EC defines each as:

(a) direct discrimination shall be taken to occur where one person is treated less favourably than another is, has been or would be treated in a comparable situation, on any of the grounds referred to in Article $1 ;^{16}$

(b) indirect discrimination shall be taken to occur where an apparently neutral provision, criterion or practice would put persons having a particular religion or belief, a particular disability, a particular age, or a particular sexual orientation at a particular disadvantage compared with other persons unless:

(i) that provision, criterion or practice is objectively justified by a legitimate aim and the means of achieving that aim are appropriate and necessary. ${ }^{17}$

\subsection{The comparator}

To demonstrate discrimination in cases of direct and indirect discrimination, it is necessary to identify a comparator. "Unfavourable treatment will be relevant to making a determination of discrimination where it is unfavourable by comparison to someone in a similar situation... Therefore a 'comparator' is needed: that is, a person in materially similar circumstances, with the main difference between the two persons being the "protected ground." 18

\footnotetext{
${ }^{15}$ European Disability Strategy (2010-2020) A Renewed Commitment to a Barrier-Free Europe for Disabled Persons-COM(2010) 636 final, http://eur-lex.europa.eu/legal-content/EN/TXT/?uri= URISERV\%3Aem0047.

${ }^{16}$ Article 1 of Council Directive 2000/78/EC The purpose of this Directive is to lay down a general framework for combating discrimination on the grounds of religion or belief, disability, age or sexual orientation as regards employment and occupation, with a view to putting into effect in the Member States the principle of equal treatment.

${ }^{17}$ Council Directive 2000/78/EC of 27 November 2000 establishing a general framework for equal treatment in employment and occupation, OJ L 303 of 2 December 2000, pp. 16-22.

${ }^{18}$ European Union Agency for Fundamental Rights [2], p. 23.
} 
Arguably the comparator with respect to disabled people not being able to export a special non-contributory benefit is 'insured persons without a disability'. Insured persons without a disability are much less likely than disabled people to be subject to a limitation to the export of their benefits.

Taking the United Kingdom as an example, the UK lists Employment and Support Allowance (ESA) Income-related ${ }^{19}$ in Annex X of Regulation 883/04. The rationale for the inclusion of Income-related Employment and Support Allowance in the Annex is set out in Commission Proposal COM (2010) 794, 20 December 2010:20

"In the Section "UNITED KINGDOM" a new special non-contributory cash benefit will be listed for UK, namely the Employment and Support Allowance Incomerelated (herewith ESA (IR)). The prime objective of the ESA (IR) is to guarantee a minimum subsistence income having regard to the economic and social situation in the UK. Income-related ESA is available where a person's contribution record or financial situation is such that no, or inadequate, contributory Employment and Support Allowance is payable. ESA (IR) was considered by the Administrative Commission to be a special non-contributory cash benefit in the sense of Article 70 of Regulation (EC) No 883/2004 that could be listed in Annex X to Regulation (EC) No 883/2004."

There are two types of Employment and Support Allowance:

- Contribution-based Employment and Support Allowance, which is paid on the basis of National Insurance contributions paid in the previous two to three full tax years.

- Income-related Employment and Support Allowance, which is means tested for people who are on a low income and have little or no savings.

Following a 'Work Capability Assessment' a disabled claimant may be placed in either the 'Work-related activity group' or the 'Support group'. If placed in the workrelated activity group she or he must attend regular interviews with an employment adviser with a view to entering or returning to work. If they fail to attend these meetings and to take agreed actions they may be sanctioned and lose some or all of their benefits. A person is placed in the Support Group if their illness or disability severely limits what they can do. People in the Support Group may-but are not required to-attend interviews with an adviser. ${ }^{21}$

The UK government has limited the period for which Contribution-based Employment and Support Allowance can be paid in some circumstances. Recipients who had already received 365 days of Contribution-based Employment and Support Allowance saw their entitlement end on 30 April 2012. There is no time limit on Contribution-based Employment and Support Allowance if in the Support Group and no time limit on Income-related Employment and Support Allowance.

Data for November 2015 show that there were 484,450 people in receipt of Contribution-based Employment and Support Allowance and 1,398,960 people in

\footnotetext{
${ }^{19}$ Welfare Reform Act 2007 and Welfare Reform Act (Northern Ireland) 2007.

${ }^{20}$ Commission Proposal COM (2010) 794, 20 December 2010.

${ }^{21}$ Gov.UK, https://www.gov.uk/employment-support-allowance/overview.
} 


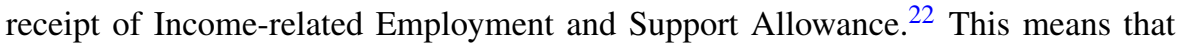
three-quarters of people claiming the UK's main disability benefit-Employment and Support Allowance - are unable to export it under EU coordinating regulations.

According to the UK's Labour Force Survey disabled people are significantly less likely to be in employment than non-disabled people. In 2012, 46.3 per cent of disabled people of working-age were in employment compared to 76.4 per cent of nondisabled people of working age. This represents a 30.1 percentage point gap between disabled and non-disabled people-over 2 million people. ${ }^{23}$

This has implications for disabled people's access to long-term contribution-based disability benefits and consequently freedom of movement. This is a consequence of the interface between many disabled people's working biographies and the long contribution requirements for many disability benefits in EU member countries. Research by Lhernould et al. found that the "rights of people to invalidity pensions are particularly sensitive to the conditions for earning entitlement to benefits... Conditions concerning continuity or duration of employment in the period directly preceding an application for an invalidity pension can result in depriving people on short-term, temporary or part-time employment contracts of the right to invalidity benefits. In many case study countries access to invalidity pensions could be restricted for workers with interrupted careers due to their long qualifying periods... In France, Ireland, Italy, the Netherlands and the UK, eligibility criteria that require minimum periods of employment or amount of contributions within given periods may lead to the exclusion of short-term and/or part-time workers from access to invalidity pensions." ${ }^{24}$ As a consequence many disabled people may need to rely on benefits that are classed as special non-contributory under EU regulations.

People with disabilities may also be disadvantaged by the classification of meanstested old age pensions as special non-contributory benefits as many EU member countries require long insurance periods to qualify for old age pensions. Lhernould et al. found that contributory schemes may require a minimum contribution period in order to qualify for any old age pension. "Belgium, the Czech Republic and Italy... require at least 20 years insurance to qualify for any pension. Poland requires 20 years insurance for women and 25 for men to qualify for a guaranteed minimum pension... In France the length of the insurance period required for a full pension has been regularly extended (it is now 41 years)... In Germany 'standard pension' is available after 45 years of insurance..." 25 The UK requires 30 qualifying years of National Insurance contributions or credits to get the full basic State Pension. Regulations excluding persons with low earnings and part-time workers can result in exclusion from statutory pension schemes for people with disabilities "who are more likely to have low earnings, short-term, seasonal or part-time work." 26 As a consequence, many disabled people fail to qualify for the maximum or, in many cases,

\footnotetext{
${ }^{22}$ Department for Work and Pensions, Quarterly Benefits Summary—Great Britain statistics to November 2015, released May 2016.

${ }^{23}$ Gov.UK Official Statistics Published 16 January 2014, https://www.gov.uk/government/publications/ disability-facts-and-figures/disability-facts-and-figures.

${ }^{24}$ Lhernould/Roberts/Steinhilber/Wóycicka [4].

${ }^{25}$ Lhernould/Roberts/Steinhilber/Wóycicka [4].

${ }^{26}$ Lhernould/Roberts/Steinhilber/Wóycicka [4].
} 
any contributory State pension. In the UK, those people, including disabled people, whose working biographies mean they do not have a sufficient contribution record for a full State pension, may claim the means-tested Pension Credit. Pension Credit is listed in Annex X of Regulation 883/04 as a special non-contributory benefit and therefore not exportable under the EU coordinating regulations. ${ }^{27}$

Research by Perren et al. found that, when presented with unlawful scenarios connected to the UK Equality Act 2010, employers were significantly less supportive of equality for disabled people than for the other protected characteristics under the Act:

"If the 'totally supportive' scores... are compared to those for gender equality, then the percentage point reductions, by sector, for disability are considerable; 20 percentage points for the private sector; 24 percentage points for the VCSE (voluntary, community and social enterprise sector organisations) and public sectors... The scenario of the disabled employee who was not promoted because s/he had taken substantial sick leave prompted the largest number of free text responses. Without exception, no distinction was made between sick leave related to the employee's disability and unrelated sick leave... 'Fairness' in the workplace was viewed as treating everyone the same regardless of personal characteristics. Some clearly had no understanding of their responsibilities under the Equality Act". 28

Similar circumstances that disadvantage or discriminate exist across the EU as a consequence of the interface between many disabled people's working biographiesincluding as a result of discrimination by employers - and entitlement conditions to contributory benefits.

\subsection{A legal ground?}

Section 4.1 above establishes that there is a difference of treatment between people with a disability and insured persons without a disability. The issue at stake is whether that difference of treatment is contrary to EU non-discrimination legislation. To establish that there is a discrimination prohibited by EU law, it is necessary to find a legal ground. The CJEU has ruled that Article 19 TFEU does not have a direct effect. Directive 2000/78 does not apply to payments of any kind made by state schemes or similar, including state social security or social protection schemes (Art. 3.3). Can a legal ground be found in the United Nations Convention on the Rights of Persons with Disabilities? ${ }^{29}$

"The UNCRPD contains an extensive list of rights for persons with disabilities, aimed at securing equality in the enjoyment of their rights, as well as imposing a range of obligations on the State to undertake positive measures. Like the Charter,

\footnotetext{
${ }^{27}$ The inclusion of the UK Pension Credit in Annex X of Regulation 883/04 as a special non-contributory benefit may discriminate against women as well as disabled people. UK official data for November 2015 giving a breakdown of total claims for UK Pension Credit show a large gender difference. Of the total claims of 2.04 million, $38 \%$ were by men and $62 \%$ by women (Department for Work and Pensions, Quarterly Benefits Summary-Great Britain statistics to November 2015, released May 2016). As with disabled people, this is a reflection of the interface of women's working biographies with the contribution requirements for a full state pension.

${ }^{28}$ Perren/Roberts/Stafford/Hirsch [5], p. 17.

${ }^{29}$ Sibley/Widmann [8].
} 
this binds the EU institutions, and will bind the Member States when they are applying $E U$ law... By ratifying, the EU is committed to promoting and protecting the full enjoyment of human rights by disabled people and ensuring they have full equality under the law."30

In Case C-354/13, the CJEU refers to the UN Convention on the Rights of Persons with Disabilities for the interpretation of Directive 2000/78 to establish a link between both instruments:

"The concept of 'disability' is not defined by Directive 2000/78, and nor does the directive refer to the laws of the Member States for its definition. Thus, an autonomous and uniform interpretation of 'disability' has been developed in the Court's case-law, and more recently against the background of the United Nations Convention on the Rights of Persons with Disabilities, which the European Union approved by a decision of 26 November 2009. The Convention forms an integral part of the EU legal order from its time of entry into force. It is also worth emphasising that Directive 2000/78 must, as far as possible, be interpreted in a manner that is consistent with the UN Convention." 31

Although both instruments are connected, as noted above Directive 2000/78 does not apply to payments of any kind made by state schemes or similar, including state social security or social protection schemes (Art. 3.3).

However, as the EU is a party to the United Nations Convention on the Rights of Persons with Disabilities the CJEU "will most probably be guided by both the Convention itself and the interpretations given by the Committee on the Rights of Persons with Disabilities, charged with its monitoring and interpretation." 32

In its concluding observations on the initial report of the European Union on 2 October 2015, the Committee on the Rights of Persons with Disabilities recommended that the European Union "conduct a cross-cutting, comprehensive review of its legislation in order to ensure full harmonisation with the provisions of the Convention, and actively involve representative organisations of persons with disabilities and independent human rights institutions in the process. It also recommends the adoption of a strategy on the implementation of the Convention, with the allocation of a budget, a time frame for implementation and a monitoring mechanism."33

With reference to Equality and non-discrimination (art. 5), the Committee recommended that the European Union "adopt its proposed horizontal directive on equal treatment, extending protection against discrimination to persons with disabilities, including by the provision of reasonable accommodation in all areas of competence, The Committee also recommends that the European Union ensure that discrimination in all aspects on the grounds of disability is prohibited, including multiple and intersectional discrimination." 34

\footnotetext{
${ }^{30}$ European Union Agency for Fundamental Rights [2].

${ }^{31}$ Case C-354/13 Fag og Arbejde (FOA) v Kommunernes Landsforening (KL), ECLI:EU:C:2014:2463.

${ }^{32}$ European Union Agency for Fundamental Rights [2].

${ }^{33}$ United Nations Committee on the Rights of Persons with Disabilities 'Concluding observations on the initial report of the European Union', 2 October 2015.

${ }^{34}$ Ibid.
} 


\subsection{Justification-between the devil and the deep blue sea}

If the difference of treatment were to fall within the scope of EU law, including under obligations deriving from the UN Convention, the question follows whether a measure that discriminates can be justified.

Paragraph 4 of Article 70 of Regulation 883/04 states that "The benefits referred to in paragraph 2 shall be provided exclusively in the Member State in which the persons concerned reside, in accordance with its legislation. Such benefits shall be provided by and at the expense of the institution of the place of residence." Thus, the rationale of the special non-contributory benefit is not to withdraw a benefit but to change the competent state so a person who moves from, for example, the UK to France loses the UK benefit but gains the equivalent French benefit.

This is in keeping with the general principles of coordination set out in Article 11 of Regulation 883/04 which establishes the rules to determine which Member State is responsible for the payment of benefits. Article 11 establishes that people who are economically inactive and not covered by its Articles 11(3)(a) to (d) are subject to the legislation of the state of residence under Article 11(3)(e). The general principle of coordination is therefore that the state of employment is responsible for the benefits of economically active people (Lex loci laboris principle) and the state of residence is responsible for the benefits of economically inactive people (Lex loci domicilii principle).

However, although the rationale of the special non-contributory benefit is not to withdraw a benefit but to change the competent state the effect in practice is in many cases to withdraw a benefit from disabled people who wish to exercise their 'right' to free movement. This is because several member countries do not have an equivalent benefit for disabled people and those that do have increasingly attached residence conditions to control access to their benefits that are categorised as 'special non-contributory benefits'. The UK, for example, has a complex mix of multiple residency-related tests controlling access to benefits for 'people from abroad'. 35

The UK's residence requirements were ratcheted up in 1994 with the introduction of the 'Habitual Residence Test'. ${ }^{36}$ The test now applies to the receipt of the noncontributory income-based benefits: Income Support, Income-based Jobseeker's Allowance, Income-related Employment and Support Allowance, Pension Credit, Housing Benefit, Council Tax Reduction and Universal Credit. EU nationals who have the right of residence under EU legislation because they have worked in the UK are exempt from the requirement to be habitually resident. Other EU nationals, including jobseekers, are subject to the test.

The Social Security (Habitual Residence) Amendment Regulations $2004^{37}$ became effective on 1 May 2004-the day workers from the Central and Eastern European accession countries were permitted to enter the UK. The amendment introduced a further test for receipt of the income-related benefits including Income-related Employment and Support Allowance which requires a claimant-in addition to being

\footnotetext{
${ }^{35}$ Roberts [7].

${ }^{36}$ Miscellaneous Amendments (No. 3) Regulations 1994 (SI 1994 No. 1807).

${ }^{37}$ Statutory Instruments, 2004 No. 1232 Social Security, The Social Security (Habitual Residence) Amendment Regulations 2004.
} 
present and habitually resident - to have a 'right to reside' under UK or EU law in the 'Common Travel Area' (the UK, the Republic of Ireland, the Channel Islands or the Isle of Man). The Right to Reside Test has been subject to several legal challenges in the UK and in June 2015, the European Commission argued before the CJEU that the UK government "has created a situation of direct discrimination" as the Test places additional conditions on EU nationals that are not required of UK citizens. ${ }^{38}$

The combination of Article 70 and Annex X of Regulation 883/04 with national residence tests applied to many special non-contributory benefits across the EU may mean that people with disabilities find themselves trapped between the 'devil' of residence tests and the 'deep blue sea' of special non-contributory benefits when it comes to trying to exercise their 'right' to free movement.

\section{Conclusions}

The questions whether the difference of treatment identified in Sect. 4.1 falls within the scope of EU law, including under obligations deriving from the UN Convention, and whether any discrimination could be justified, are left open. However, the restriction on exporting some important benefits for disabled people raises 'philosophical' questions about the nature and purpose of social security. Social security is a social contract to share life's risks, including that of disability, in order to avoid poverty, maintain a decent standard of living and facilitate opportunity.

However, as shown in Sect. 4.3, EU member countries have increasingly attached residence conditions to control access to special non-contributory benefits with the consequence that a disabled person cannot export their special non-contributory benefits but at the same time in many cases neither can they gain access to similar benefits in the destination country. This situation is repeated around the European Union with the effect of denying free movement opportunities to many people with disabilities.

The justification for the non-exportability of special non-contributory benefits can be found in the 'communitarian' view of 'community'. For communitarians, the modern 'nation state' is bound together by the "solidarities implicit in a common tax and public service system." 39 However, according to communitarians, "the solidarities that exist within the nation state do not, or rarely, exist cross-nationally or between states. It is this fact above all that ties the redistributive welfare state irrevocably to the national level." 40 The rationale of special non-contributory benefits is that they are a financial expression of the solidarity within a Member State, and this financial form of solidarity does not travel beyond national borders. This view of community is challenged by the European Union, and in particular by free movement of workers and cross-border social security which broaden the conception of the boundary of shared risks.

The situation whereby many people with disabilities may find themselves trapped between the 'devil' of residence tests and the 'deep blue sea' of special noncontributory benefits should they want to exercise their right to free movement

\footnotetext{
${ }^{38}$ BBC News 11 August 2015, http://www.bbc.co.uk/news/uk-33850247, cited by Roberts [7].

${ }^{39}$ Coughlan [1], p. 112.

${ }^{40}$ Coughlan [1], p. 112.
} 
suggests that cross-border solidarity is, despite the manifold statements of good intentions, in practice weak for disabled people. It is proposed that special noncontributory benefits are included in a review of the compatibility of EU legislation with the United Nations Convention on the Rights of Persons with Disabilities to examine whether they comply with obligations under the Convention with a view to translating high-level aspirational statements into substantive rights that provide full citizenship for Europe's disabled people including equality of opportunity to access Europe's labour markets and cultural spaces.

Acknowledgements The author is grateful to Professor Jean-Philippe Lhernould for his comments on an earlier draft. All errors and shortcomings are of course the sole responsibility of the author.

Open Access This article is distributed under the terms of the Creative Commons Attribution 4.0 International License (http://creativecommons.org/licenses/by/4.0/), which permits unrestricted use, distribution, and reproduction in any medium, provided you give appropriate credit to the original author(s) and the source, provide a link to the Creative Commons license, and indicate if changes were made.

\section{References}

1. Coughlan, A.: 'The Limits of Solidarity: Social Policy, National and International'. Paper given to '50 Years after Beveridge' conference at University of York, 27-30 September, vol. 2. York, SPRU (1992)

2. European Agency for Fundamental Rights/European Court of Human Rights/Council of Europe: Handbook on European Non-discrimination Law. Luxembourg, Publications Office of the European Union. http://fra.europa.eu/en/publication/2011/handbook-european-non-discrimination-law

3. Holloway, J.: Social Policy Harmonisation in the European Community, Farnborough, Gower (1981)

4. Lhernould, J.-P., Roberts, S., Steinhilber, S., Wóycicka, I.: Study of the gender dimension and discrimination in social protection. Report to the European Commission, DG Employment, Social Affairs and Equal Opportunities under the Progress Programme (2010)

5. Perren, K., Roberts, S., Stafford, B., Hirsch, D.: Evaluation of the Implementation of the Equality Act 2010: Report 2-Awareness and Impact of the Equality Act. Stationery Office (2012)

6. Roberts, S.: A short history of social security coordination. In: 50 Years of Social Security Coordination. Luxembourg Publications Office of the European Union, Luxembourg (2010)

7. Roberts, S.: The Xenophobe's Phrase Book Zeitschrift für ausländisches und internationales Arbeitsund Sozialrecht, pp. 185-200. Max Planck Institute, Munich (2016)

8. Sibley, E., Widmann, M.: Welfare benefits for marginalised migrants: special non-contributory benefits in the UK, The Republic of Ireland \& The Netherlands. The AIRE Centre, London

9. Watson, P.: Social Security Law of the European Communities. Mansell, London (1980) 